\title{
Substrates and nutrient addition rates affect morphology and physiology of Pinus leiophylla seedlings in the nursery stage
}

Mayra Velén Buendía Velázquez, Miguel Ángel López López, Víctor Diakite Manuel Cetina Alcalá, Lamine

\begin{abstract}
Production of forest seedlings is expensive mainly due to the use of inputs such as peat moss and fertilizers. Seedling survival in field conditions is low when seedlings with limited internal nutrient reserves are used in low fertility sites. In this work, raw sawdust and exponential fertilization were tested against peat-moss and constant fertilization, the common components of containerized seedling production systems in Mexico. The experiment was carried out under nursery conditions by using a complete randomized experimental design with a $2 \times 2$ factorial arrangement. Two substrates peat-moss (PM) and sawdust (SA) and two nutrient addition rates constant (CR) and exponential (ER) were tested. The response of seedlings was assessed based on diameter at the root collar, seedling height, dry weight (shoot, root, total and 100-needle), Dickson quality index (DQI), slenderness index (SI), and foliar nutrient concentrations and contents. Analysis of variance indicated that the substrate significantly affect all dry weights, with the greatest biomass observed for PM. Similarly, DQI and SI were affected by the substrate, with PM showing the best DQI and highest SI. Neither plant quality variables nor dry weights were affected by nutrient addition rates. Both substrate and nutrient addition rate significantly affected $\mathrm{N}, \mathrm{P}$, and $\mathrm{K}$ foliar concentrations. At the end of the production cycle, SA promoted higher foliar concentrations of $N$ and $P$ than $P M$, but not those of $\mathrm{K}$. This suggests that $\mathrm{K}$ limited the growth of seedlings in sawdust, likely due to the low capacity of this substrate to adsorb K. ER produced needle concentrations of $\mathrm{N}, \mathrm{P}$, and $\mathrm{K}$ significantly higher than those of CR (2.65 vs. $2.26 \%, 2303$ vs. $2011 \mathrm{ppm}$, and 4235 vs. $3949 \mathrm{ppm}$, respectively). Our results indicate that ER is likely to give rise to more suited seedlings for outplanting in low fertility sites than CR.
\end{abstract}

Keywords: Pinus leiophylla, Peat-moss, Sawdust, Constant and Exponential Fertilization Rate tions (Hernández et al. 2014); however, more research is needed in order to fully understand its behavior under a variety of conditions.

Along with high production costs in the nursery, seedling survival in the field frequently is low, mainly at low fertility sites. It has been reported for 2011 a reduction in the field survival at a national level, including temperate forests, rain forests and arid lands, from 57.5 to $40.28 \%$ (UACH/CEC 2011), with drought and the low morphological quality of plants being the main
Colegio de Postgraduados Campus Montecillo, Carretera México-Texcoco Km 36.5, 56230 Montecillo (Mexico)

@ Miguel Ángel López López (lopezma@colpos.mx)

Received: Jan 12, 2016 - Accepted: Jun 12, 2016

Citation: Buendía Velázquez MV, López López MÁ, Cetina Alcalá VM, Diakite L (2016). Substrates and nutrient addition rates affect morphology and physiology of Pinus leiophylla seedlings in the nursery stage. iForest 10: 115-120. - doi: 10.3832/ifor1982-009 [online 201610-02]

Communicated by: Giustino Tonon mortality causes. Since most afforestation programs take place on degraded and nutrient-poor soils, it is important to enhance nutrient reserves of seedlings at the nursery stage. The exponential addition rate scheme (Timmer \& Stone 1978) may help achieve this goal.

UACH/CEC (2011) reports Cedrela odorata as the most commonly planted and nursery-grown species in Mexico. For temperate climate, Chihuahua pine (Pinus leiophylla Schiede ex Schltdl. \& Cham.) shows characteristics of both soft and hard pines, and is widely distributed over several states of the country, including the State of Mexico (Echenique 1969, cited by Musalem \& Martínez 2003). Its resistance to adverse conditions is widely appreciated, so that it is considered a pioneer species growing even on poor soils and on lands covered with volcanic lava (Santillán 1991). Recent studies support its resistance to water stress levels as low as -3.5 MPa (Castelán Munoz 2014).

In the present study, the effect of two different substrates and two nutrient addition rates on morphological and physiological variables of Pinus leiophylla seedlings were evaluated at the forest nursery of 
Colegio de Postgraduados, Campus Montecillo, Texcoco, State of Mexico.

The first null hypothesis $\left(\mathrm{Ho}_{1}\right)$ tested in this study assumes that the factor "substrate" (mixtures of peat-moss-perlite-vermiculite [PM] or sawdust-perlite-vermiculite [SA]) do not produce significant differences on morphological or physiological quality of nursery seedlings. The second null hypothesis $\left(\mathrm{HO}_{2}\right)$ states that the levels of the factor "nutrient addition rate" (i.e., exponential [ER] and constant [CR]) do not induce significant differences on morphological or physiological quality of nursery stage seedlings. The third null hypothesis $\left(\mathrm{Ho}_{3}\right)$ assumes that there is no interaction between the factors "substrate" and "nutrient addition rate".

\section{Materials and methods}

The experiment was carried out from November 2013 to August 2014, in the nursery of Colegio de Postgraduados, Campus Montecillo, Texcoco, State of Mexico. The site has a temperate sub-humid climate, with rainfall in summer, an average temperature of $15.5^{\circ} \mathrm{C}$, an average annual rainfall of $750 \mathrm{~mm}$, a relative humidity of 70 to $85 \%$, and a photoperiod of $15 \mathrm{~h}$.

Pinus Leiophylla seeds were donated by the San Luis Tlaxialtemalco nursery in Mexico, D.F. (Distrito Federal Commission for Natural Resources, CORENA). The original seed source was located in the Tlahuapan Municipality, in the State of Puebla, Mexico. Five-hundred seeds were selected and submerged in water for 24 hours before direct sowing. The seeds were sown in 346 $\mathrm{cm}^{3}$ tubes containing a dominant mixture of peat-moss (PM), or sawdust (SA) as substrate, previously pasteurized.

The experiment was established under a complete randomized experimental design (CRD) with a factorial $2 \times 2$ arrangement of treatments. The experimental unit was a set of 25 individuals and each treatment was replicated four times. The first factor was "Substrate" with two levels: PM (60\% peat-moss, $20 \%$ perlite, and $20 \%$ vermiculite), and SA (60\% raw sawdust, $20 \%$ perlite, and $20 \%$ vermiculite). The second factor was "Nutrient addition rate" with two levels: constant (CR) and exponential (ER). In the constant fertilization rate (CR), a constant amount of nutrients $(0.395 \mathrm{~g} \mathrm{~N}$ plant $^{-1}, 0.086 \mathrm{~g} \mathrm{P}$ plant $^{-1}$, and $0.328 \mathrm{~g} \mathrm{~K}^{-}$ plant $\left.{ }^{-1}\right)$ was applied along the whole experimental cycle (36 application dates). Nutrient dose calculations were based on Aldana \& Aguilera (2003) for conifers including $P$. leiophylla, considering nutrient inputs by both soluble and slow-release fertilizer materials.

Calculations for the exponential rate (ER) were based on the exponential function described by Miller \& Timmer (1994). The same amount of fertilizing material was used (PETERS 20-10-20) as in the constant fertilization ( 0.395 grams $N$ plant $^{-1}$ and the corresponding amounts of $\mathrm{P}$ and $\mathrm{K}$ ) throughout the production cycle. How- ever, in this case, nutrient dose varied exponentially throughout the experimental period, so that a dose of $0.00011 \mathrm{~g} \mathrm{~N}$ plant $^{-1}$ was supplied on the first application date and the cumulative amount of $0.395 \mathrm{~g} \mathrm{~N}$ plant $^{-1}$ was reached on the $36^{\text {th }}$ application date.

To calculate the dose of Peters 20-10-20 to be applied on each date, we considered the mean nitrogen content of three Pinus leiophylla seedlings just after germination (biomass $=0.2 \mathrm{mg}$ ) as well as that of three commercial-size seedlings $25 \mathrm{~cm}$ in height (biomass $=40 \mathrm{mg}$ ), and used the Miller \& Timmer (1994) model to calculate the relative addition rate $(r-$ eqn. 1$)$ :

$$
N_{T}=N_{S}\left(e^{r t}-1\right)
$$

where $N_{\mathrm{T}}$ is the desired increment in the nutrient content of the seedling during $t$ applications $(\mathrm{mg}), N_{\mathrm{s}}$ is the initial nutrient content in the seedling $(\mathrm{mg}), r$ is the nutrient addition rate $\left(\%\right.$ day $\left.^{-1}\right)$, and $t$ is the number of application of fertilizer in the application sequence.

The calculated relative addition rate was used to distribute the amount of fertilizing material ( $0.395 \mathrm{~g}$ of $\mathrm{N}$ per plant) among all application dates, following the recommendation by Aldana \& Aguilera (2003). The use of a single nutrient addition rate, coupled with the seedling growth rate, ensured a steady state of the internal concentration of nutrients. This procedure also allowed comparing the effectiveness of the addition rates tested with each other, as the total amount of fertilizing material used for both addition rates was identical at the end of the cycle.

Germination was completed in January 2014, and nutrient addition treatments started in April 2014, once that the succulent stage of seedlings was concluded, and damping off was unlikely to occur. Both fertilization regimes used Peter's fertilizer 20-10-20, with 36 applications in total, two per week, during four months and a half. Fertilization was the only source of nutrients, since the remaining irrigation events consisted of application of distilled water only. During the experimental period, treatment effects were evaluated based on twelve morphological and physiological variables: (1) root-collar diameter ( $D, \mathrm{~mm}$ ), measured by using a digital caliper Truper ${ }^{\oplus}$; (2) total height $(\mathrm{H}, \mathrm{cm})$, measured monthly with a ruler; (3) root biomass (RDW); (4) stem biomass (SDW); (5) 100-needle biomass (100-needle DW), and (6) total dry weights (TDW). Dry weights were determined in July 2014, after drying the material in a Felisa ${ }^{\oplus}$ oven at $70^{\circ} \mathrm{C}$ for 48 h. Relative growth rates of (7) diameter (RGRD) and (8) height (RGRH) were also evaluated based on the following general equation (Pallardy 2008 - eqn. 2):

$$
R G R=\frac{\ln \left(X_{2}\right)-\ln \left(X_{1}\right)}{\Delta t}
$$

where $X_{1}$ and $X_{2}$ are the variables measured in the first and last evaluation dates, respectively, and $\Delta t$ is the time elapsed between the two measurements. (9) The Slenderness index (SI) was calculated, as the ratio between shoot height and rootcollar diameter (Johnson \& Cline 1991). Additionally, the (10) Dickson Quality Index (DQI - Dickson et al. 1960) was calculated as follows (eqn. 3 ):

$$
D Q I=\frac{T D W}{(H / D)+(A D W / R D W)}
$$

where $T D W$ is the total biomass (g), $H$ is the height $(\mathrm{cm}), D$ is the diameter $(\mathrm{mm})$, $A D W$ is the aboveground dry weight (g) and $R D W$ is the root dry weight (g).

At the end of the experiment, 16 composite samples of needles were prepared, one for each experimental unit (four per treatment), to determine (11) the foliar nutrient concentrations. Nitrogen ( $\mathrm{N}$ ) concentration was determined by the Kjeldahl method, while phosphorus (P) and potassium (K) by humid digestion with perchloric and nitric acids. (12) Foliar nutrient contents $(\mathrm{N}$, $P, K$ ) were derived from 100-needle dry weights and foliar nutrient concentrations.

The effect of factors and their interactions on the morphological and physiological variables were tested by ANOVA using the SAS package. Effects were considered statistically significant when $\mathrm{p}<0.05$ (reliability $>95 \%$ ). The post-hoc Tukey's test ( $\alpha=$ 0.05 ) was used to test for differences between treatment means of significant factors. To interpret $\mathrm{N}, \mathrm{P}$, and $\mathrm{K}$ concentrations and contents, the graphical vector analysis method was used (Timmer \& Stone (1978). Interpretation of the nomograms was based on López \& Alvarado (2010) and Haase \& Rose (1995).

\section{Results}

\section{Morphological variables}

The results of ANOVA and Tukey's tests on seedling growth and quality variables are reported in Tab. 1. Both nutrient addition rate and substrate showed a significant effect on seedling diameter (D) and height $(\mathrm{H})$. Nutrient addition rate significantly affected the dry weight of 100 needles (100-needle DW1) and relative growth rate in diameter (RGRD). However, it did not show any significant effect on RDW, SDW, TDW, RGRH, DQI, and SI (Tab. 1). Seedlings grown under the $C R$ treatment showed significantly higher values of $D, H$, 100-needle DW and RGRD. The substrate significantly affected $(p<0.05)$ all variables except RGRD ( $p=0.1404)$. According to Tukey's tests, higher mean values were observed for seedlings grown on the PM substrate (Tab. 1).

Fig. 1 illustrates the interaction $\mathrm{PM} \times \mathrm{CR}$ (peat-moss substrate and constant nutrient addition rate). This treatment showed the highest means for the morphological variables D (Fig. 1A), H (Fig. 1B), RDW (Fig. 1C), SDW (Fig. 1D), 100-needle DW (Fig. 1E), TDW (Fig. 1F), and DQI (Fig. 1J). The highest 
Tab. 1 - Results of the analysis of variance on morphological variables. Different letters within the same factor indicate significant differences between means after Tukey's test $(p<0.05)$.

\begin{tabular}{|c|c|c|c|c|c|c|c|c|c|c|c|}
\hline Variable & $\begin{array}{l}\text { Source of } \\
\text { variation }\end{array}$ & $\begin{array}{l}\text { Treat } \\
\text { ment }\end{array}$ & Mean & F-value & Prob & Variable & $\begin{array}{l}\text { Source of } \\
\text { variation }\end{array}$ & $\begin{array}{l}\text { Treat } \\
\text { ment }\end{array}$ & Mean & F-value & Prob \\
\hline \multirow{3}{*}{$\begin{array}{l}\text { Root-collar } \\
\text { diameter } \\
(\mathrm{D}, \mathrm{mm})\end{array}$} & Model & - & - & 106.88 & $<.0001$ & \multirow{3}{*}{$\begin{array}{l}\text { Total dry } \\
\text { weight } \\
\text { (TDW, g) }\end{array}$} & Model & - & - & 7.75 & 0.0038 \\
\hline & Substrate & $\begin{array}{l}\text { SA } \\
\text { PM }\end{array}$ & $\begin{array}{l}2.298^{b} \\
4.576^{a}\end{array}$ & 233.40 & $<.0001$ & & Substrate & $\begin{array}{l}\text { SA } \\
\text { PM }\end{array}$ & $\begin{array}{l}0.409^{b} \\
2.131^{a}\end{array}$ & 233.40 & 0.0007 \\
\hline & $\begin{array}{l}\text { Nutrient } \\
\text { addition rate }\end{array}$ & $\begin{array}{l}\text { CR } \\
\text { ER }\end{array}$ & $\begin{array}{l}3.980^{\mathrm{a}} \\
2.893^{\mathrm{b}}\end{array}$ & 53.17 & $<.0001$ & & $\begin{array}{l}\text { Nutrient } \\
\text { addition rate }\end{array}$ & $\begin{array}{l}\text { CR } \\
\text { ER }\end{array}$ & $\begin{array}{l}1.515^{\mathrm{a}} \\
1.025^{\mathrm{a}}\end{array}$ & 53.17 & 0.223 \\
\hline \multirow{3}{*}{$\begin{array}{l}\text { Total height } \\
(\mathrm{H}, \mathrm{cm})\end{array}$} & Model & - & - & 167.73 & $<.0001$ & \multirow{3}{*}{$\begin{array}{l}\text { Diameter } \\
\text { relative } \\
\text { growth rate } \\
\text { (RGRD) }\end{array}$} & Model & - & - & 15.92 & 0.0002 \\
\hline & Substrate & $\begin{array}{l}\text { SA } \\
\text { PM }\end{array}$ & $\begin{array}{r}5.044^{\mathrm{b}} \\
14.400^{\mathrm{a}}\end{array}$ & 422.08 & $<.0001$ & & Substrate & $\begin{array}{l}\text { SA } \\
\text { PM }\end{array}$ & $\begin{array}{l}0.008^{\mathrm{a}} \\
0.009^{\mathrm{a}}\end{array}$ & 2.49 & 0.1404 \\
\hline & $\begin{array}{l}\text { Nutrient } \\
\text { addition rate }\end{array}$ & $\begin{array}{l}\text { CR } \\
\text { ER }\end{array}$ & $\begin{array}{r}11.391^{\mathrm{a}} \\
8.052^{\mathrm{b}}\end{array}$ & 53.75 & 0.0001 & & $\begin{array}{l}\text { Nutrient } \\
\text { addition rate }\end{array}$ & $\begin{array}{l}\text { CR } \\
\text { ER }\end{array}$ & $\begin{array}{l}0.010^{\mathrm{a}} \\
0.008^{\mathrm{b}}\end{array}$ & 18.36 & 0.0011 \\
\hline \multirow[t]{2}{*}{$\begin{array}{l}\text { Root biomass } \\
\text { (RDW, g) }\end{array}$} & $\begin{array}{l}\text { Model } \\
\text { Substrate }\end{array}$ & $\begin{array}{l}- \\
\text { SA } \\
\text { PM }\end{array}$ & $\begin{array}{l}0.134^{\mathrm{b}} \\
0.457^{\mathrm{a}}\end{array}$ & $\begin{array}{r}7.21 \\
18.71\end{array}$ & $\begin{array}{l}0.005 \\
0.001\end{array}$ & \multirow{2}{*}{$\begin{array}{l}\text { Height } \\
\text { relative } \\
\text { growth rate } \\
\text { (RGRH) }\end{array}$} & $\begin{array}{l}\text { Model } \\
\text { Substrate }\end{array}$ & $\begin{array}{l}- \\
\text { SA } \\
\text { PM }\end{array}$ & $\begin{array}{l}- \\
2.461^{\mathrm{a}} \\
1.564^{\mathrm{b}}\end{array}$ & $\begin{array}{r}8.43 \\
24.81\end{array}$ & $\begin{array}{l}0.0028 \\
0.003\end{array}$ \\
\hline & $\begin{array}{l}\text { Nutrient } \\
\text { addition rate }\end{array}$ & $\begin{array}{l}\text { CR } \\
\text { ER }\end{array}$ & $\begin{array}{l}0.342^{\mathrm{a}} \\
0.249^{\mathrm{a}}\end{array}$ & 1.55 & 0.2364 & & $\begin{array}{l}\text { Nutrient } \\
\text { addition rate }\end{array}$ & $\begin{array}{l}\text { CR } \\
\text { ER }\end{array}$ & $\begin{array}{l}2.071^{\mathrm{a}} \\
1.954^{\mathrm{a}}\end{array}$ & 0.42 & 0.5306 \\
\hline \multirow{3}{*}{$\begin{array}{l}\text { Stem } \\
\text { biomass } \\
\text { (SDW, g) }\end{array}$} & Model & - & - & 7.87 & 0.0036 & \multirow{3}{*}{$\begin{array}{l}\text { Slenderness } \\
\text { index } \\
\text { (IE) }\end{array}$} & Model & - & - & 11.02 & 0.0009 \\
\hline & Substrate & $\begin{array}{l}\text { SA } \\
\text { PM }\end{array}$ & $\begin{array}{l}0.274^{\mathrm{b}} \\
1.674^{\mathrm{a}}\end{array}$ & 20.80 & 0.0007 & & Substrate & $\begin{array}{l}\text { SA } \\
\text { PM }\end{array}$ & $\begin{array}{l}21.922^{b} \\
30.919^{a}\end{array}$ & 27.52 & 0.0002 \\
\hline & $\begin{array}{l}\text { Nutrient } \\
\text { addition rate }\end{array}$ & $\begin{array}{l}\mathrm{CR} \\
\mathrm{ER}\end{array}$ & $\begin{array}{l}1.173^{\mathrm{a}} \\
0.776^{\mathrm{a}}\end{array}$ & 1.67 & 0.2206 & & $\begin{array}{l}\text { Nutrient } \\
\text { addition rate }\end{array}$ & $\begin{array}{l}C R \\
E R\end{array}$ & $\begin{array}{l}27.239^{a} \\
25.602^{b}\end{array}$ & 0.91 & 0.3585 \\
\hline 100-needle & Model & - & - & 46.29 & $<.0001$ & \multirow{3}{*}{$\begin{array}{l}\text { Dickson } \\
\text { quality } \\
\text { index (DQI) }\end{array}$} & Model & - & - & 7.17 & 0.0052 \\
\hline $\begin{array}{l}\text { biomass } \\
\text { (100-needle }\end{array}$ & Substrate & $\begin{array}{l}\text { SA } \\
\text { PM }\end{array}$ & $\begin{array}{l}1.270^{b} \\
3.191^{a}\end{array}$ & 121.36 & $<.0001$ & & Substrate & $\begin{array}{l}\text { SA } \\
\text { PM }\end{array}$ & $\begin{array}{l}0.097^{b} \\
0.316^{a}\end{array}$ & 17.50 & 0.0013 \\
\hline DW, g) & $\begin{array}{l}\text { Nutrient } \\
\text { addition rate }\end{array}$ & $\begin{array}{l}\text { CR } \\
\text { ER }\end{array}$ & $\begin{array}{l}2.529^{\mathrm{a}} \\
1.933^{\mathrm{b}}\end{array}$ & 11.68 & 0.051 & & $\begin{array}{l}\text { Nutrient } \\
\text { addition rate }\end{array}$ & $\begin{array}{l}\text { CR } \\
\text { ER }\end{array}$ & $\begin{array}{l}0.244^{\mathrm{a}} \\
0.169^{\mathrm{a}}\end{array}$ & 2.06 & 0.177 \\
\hline
\end{tabular}

Fig. 1 - Interaction of the factors tested on morphological variables. (SA): Sawdust substrate;

(PM): Peat-moss substrate; (CR): constant nutrient addition rate; (ER): exponential nutrient addition rate.
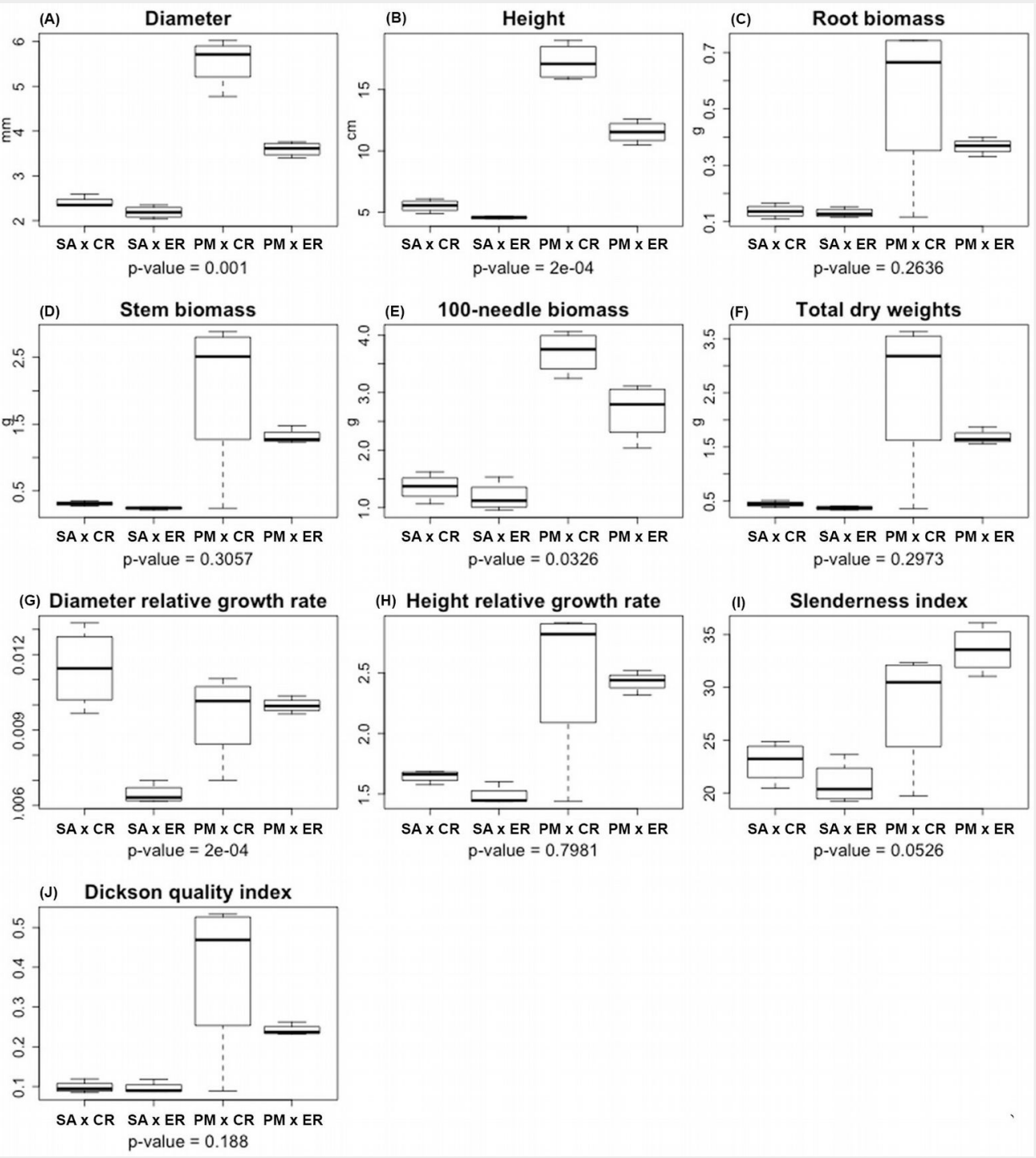
Tab. 2 - Results of the analysis of variance on physiological variables. Different letters within the same factor indicate significant differences between means after Tukey's test $(p<0.05)$

\begin{tabular}{|c|c|c|c|c|c|}
\hline Variable & $\begin{array}{l}\text { Source of } \\
\text { variation }\end{array}$ & Treatment & Mean & $F$ value & $\mathrm{Pr}>\mathrm{F}$ \\
\hline$N$ & Model & & - & 6.76 & 0.0064 \\
\hline \multirow[t]{3}{*}{$\begin{array}{l}\text { concentration } \\
(\%)\end{array}$} & Substrate & $\begin{array}{l}\text { SA } \\
\text { PM }\end{array}$ & $2.323^{b}$ & 6.2 & 0.0285 \\
\hline & $\begin{array}{l}\text { Nutrient addition } \\
\text { rate }\end{array}$ & $\begin{array}{l}\text { CR } \\
\text { ER }\end{array}$ & $2.655^{a}$ & 12.37 & 0.0042 \\
\hline & Interaction & - & - & 1.7 & 0.2167 \\
\hline$P$ & Model & - & - & 45.45 & $<.0001$ \\
\hline \multirow[t]{3}{*}{$\begin{array}{l}\text { concentration } \\
(\mathrm{ppm})\end{array}$} & Substrate & $\begin{array}{l}\text { SA } \\
\text { PM }\end{array}$ & $1819.14^{b}$ & 114.85 & $<.0001$ \\
\hline & $\begin{array}{l}\text { Nutrient addition } \\
\text { rate }\end{array}$ & $\begin{array}{l}\text { CR } \\
\text { ER }\end{array}$ & $2303.42^{a}$ & 21.47 & 0.0006 \\
\hline & Interaction & - & - & 0.03 & 0.8741 \\
\hline K & Model & - & - & 21.89 & $<.0001$ \\
\hline \multirow[t]{3}{*}{$\begin{array}{l}\text { concentration } \\
(\mathrm{ppm})\end{array}$} & Substrate & $\begin{array}{l}\text { SA } \\
\text { PM }\end{array}$ & $4513.7^{a}$ & 45.27 & $<.0001$ \\
\hline & $\begin{array}{l}\text { Nutrient addition } \\
\text { rate }\end{array}$ & $\begin{array}{l}\text { CR } \\
\text { ER }\end{array}$ & $4235.2^{a}$ & 5.21 & 0.0415 \\
\hline & Interaction & - & - & 15.19 & 0.0021 \\
\hline \multirow[t]{4}{*}{$\mathrm{N}$ content (g) } & Model & - & - & 25.1 & $<.0001$ \\
\hline & Substrate & $\begin{array}{l}\text { SA } \\
\text { PM }\end{array}$ & $0.072^{a}$ & 74.47 & $<.0001$ \\
\hline & $\begin{array}{l}\text { Nutrient addition } \\
\text { rate }\end{array}$ & $\begin{array}{l}\text { CR } \\
\text { ER }\end{array}$ & $0.054^{\mathrm{a}}$ & 0.55 & 0.4737 \\
\hline & Interaction & - & - & 0.27 & 0.6122 \\
\hline \multirow[t]{4}{*}{ P content $(\mathrm{g})$} & Model & - & - & 15.16 & 0.0002 \\
\hline & Substrate & $\begin{array}{l}\text { SA } \\
\text { PM }\end{array}$ & $0.003^{b}$ & 43.32 & $<.0001$ \\
\hline & $\begin{array}{l}\text { Nutrient addition } \\
\text { rate }\end{array}$ & $\begin{array}{l}\text { CR } \\
\text { ER }\end{array}$ & $0.0046^{a}$ & 1.08 & 0.3192 \\
\hline & Interaction & - & - & 1.08 & 0.3192 \\
\hline \multirow[t]{4}{*}{ K content $(\mathrm{g})$} & Model & - & - & 31.01 & $<.0001$ \\
\hline & Substrate & $\begin{array}{l}\text { SA } \\
\text { PM }\end{array}$ & $0.014^{\mathrm{a}}$ & 90.36 & $<.0001$ \\
\hline & $\begin{array}{l}\text { Nutrient addition } \\
\text { rate }\end{array}$ & $\begin{array}{l}\text { CR } \\
\text { ER }\end{array}$ & $0.01^{a}$ & 2.14 & 0.3192 \\
\hline & Interaction & - & - & 0.53 & 0.3192 \\
\hline
\end{tabular}

means for $D$ and $H$ were $4.57 \mathrm{~mm}$ (Fig. 1A) and $14.4 \mathrm{~cm}$ (Fig. 1B), respectively. According to the National Forestry Commission (CONAFOR, Mexico), values for root collar diameter (D) and seedling height $(H)$ in good-quality plants are $4 \mathrm{~mm}$ (optimum) and $15-25 \mathrm{~cm}$, respectively.

\section{Physiological Variables}

The results of ANOVA and Tukey's tests on nutrition variables are reported in Tab. 2. The greatest differences in foliar concentrations of $N, P$, and $K$ were recorded between substrates. The SA treatment showed higher means for $\mathrm{N}$ and $\mathrm{P}$ foliar concentrations, while PM had greater mean for $\mathrm{K}$. Contrastingly, foliar contents of N, P, and K were affected by the substrate only, being PM the substrate with the highest mean.

The nutrient addition rate had significant effects on the foliar concentration of $N, P$, and $K$, with $E R$ yielding the highest concentrations $(p<0.05)$.

Vectors drawn with solid lines in Fig. 2 indicate the effects of the substrate, and those with dashed lines indicate the effects of nutrient addition rate. The PM substrate promoted a higher accumulation of biomass in 100 needles of seedlings, regardless of the rate of nutrient addition ( $\mathrm{T}_{3}$ and T4 - Fig. 2A). On the other hand, SA seedlings had higher $\mathrm{N}$ concentrations under both addition rates ( $\mathrm{T} 1$ and $\mathrm{T} 2$ - Fig. $2 \mathrm{~A}$ ). The ER treatment showed higher foliar $\mathrm{N}$ concentrations for both substrates ( $\mathrm{T}_{2}$ and T4 - Fig. 2A).

Regarding phosphorus, the PM treatment resulted in higher dry weight of 100 needles and nutrient content than SA (T3 and T4 - Fig. 2B), while seedlings grown on SA had higher $\mathrm{P}$ concentrations regardless of
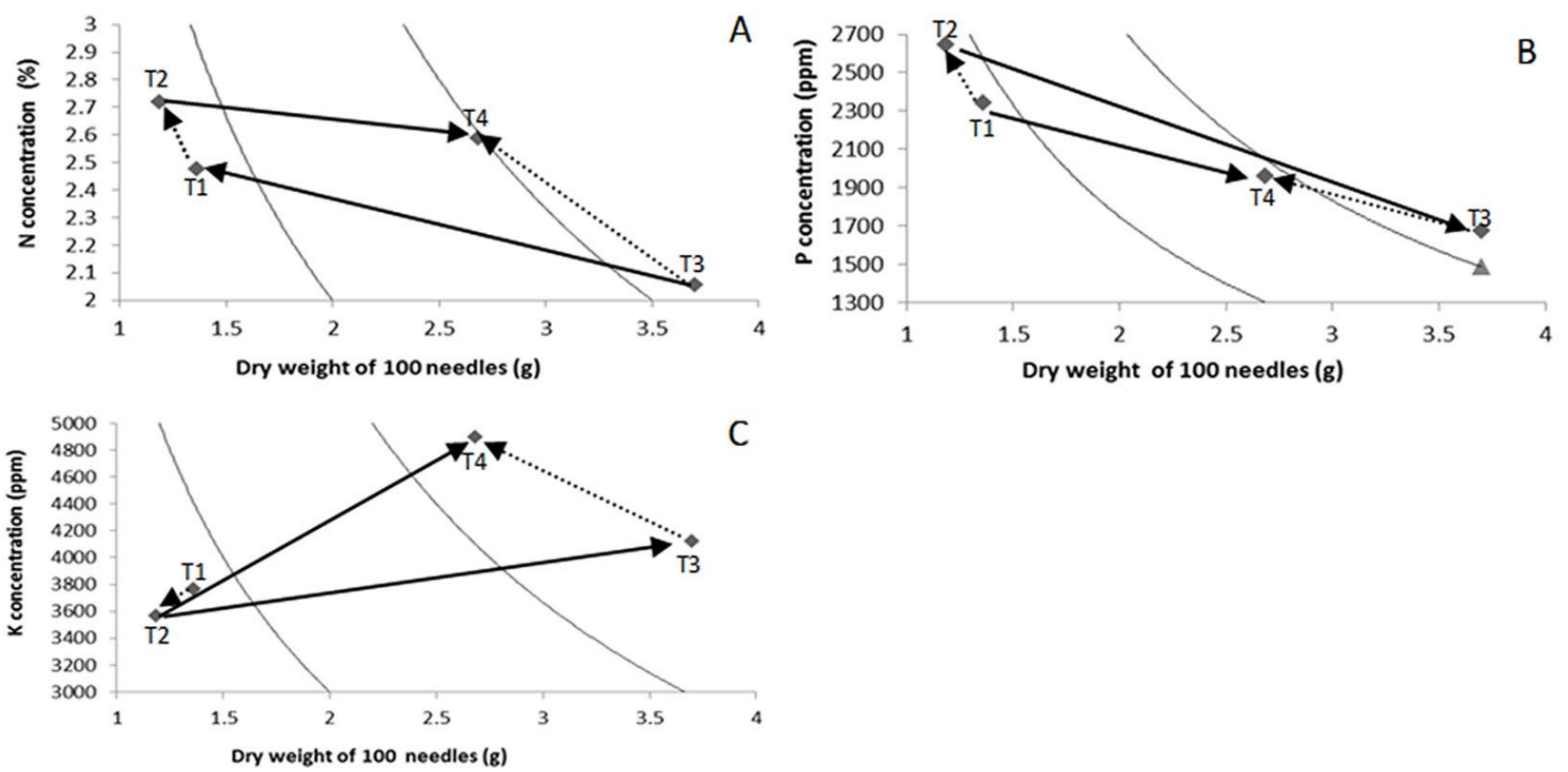

Fig. 2 - Timmer nomogramas of foliar N (A), P (B) and K (C) concentrations in Pinus leiophylla seedlings. (T1): Sawdust and constant nutrient addition rate $(\mathrm{S} A \times \mathrm{CR})$; $\left(\mathrm{T}_{2}\right)$ : Sawdust and exponential nutrient addition rate $(\mathrm{S} A \times \mathrm{ER})$; $\left(\mathrm{T}_{3}\right)$ : Peat moss and constant nutrient addition rate $(\mathrm{PM} \times \mathrm{CR})$; $(\mathrm{T} 4)$ : Peat moss and exponential nutrient addition rate $(\mathrm{PM} \times \mathrm{ER})$. 
the nutrient addition rate applied (Fig. 2B, $\mathrm{T} 1$ and $\mathrm{T} 2$ ). $\mathrm{P}$ concentration was higher in ER seedlings compared to $C R$ seedlings.

The $C R$ treatment produced more biomass of 100 needles than the ER treatment ( $\mathrm{T} 1$ vs. $\mathrm{T} 2$, and $\mathrm{T} 3$ vs. T4); however, ER (T2 and $\mathrm{T} 4$ ) promoted higher $\mathrm{P}$ concentrations regardless of the substrate used, although foliar $\mathrm{P}$ concentrations were much higher in seedlings grown on sawdust than on PM ( $\mathrm{T} 1$ and $\mathrm{T} 2$ - Fig. 2B).

As shown in Fig. $2 \mathrm{C}$ ( $\mathrm{T}_{3}$ and $\left.\mathrm{T} 4\right)$, $\mathrm{PM}$ increased both the biomass of 100 needles and the $K$ concentration and content of seedlings. The biomass of 100 needles decreased in seedlings under the ER fertilization regime, regardless of the substrate used ( $T_{2}$ and $T_{4}$ ). The PM substrate promoted higher $\mathrm{K}$ concentration with ER fertilization regime, while SA contributed to decrease it when combined with the ER treatment.

The decrease in $\mathrm{K}$ concentration and content in seedlings grown in sawdust SA $\times E R$ $(\mathrm{T} 2)$ indicates that the exponential fertilization induced a reduction of $\mathrm{K}$ availability, probably related with a lower supply of $K$ and other nutrients during the first stage of the experiment, as compared to CR. SA decreased $K$ concentration in seedlings supplied by either of the addition rates tested (Fig. 2C), but it increased those of $\mathrm{N}$ and $P$.

\section{Discussion}

In this study, the diameter and height of Pinus leiophylla seedlings were fostered by the $P M \times C R$ treatment (T3). PM-grown seedlings reached a diameter of $4.57 \mathrm{~mm}$ and a height of $14.4 \mathrm{~cm}$ at the time of harvest. According to CONAFOR (2010), seedlings of $4 \mathrm{~mm}$ in diameter and $15-25 \mathrm{~cm}$ in height are high-quality seedlings that can successfully compete with weeds in the field after transplant. However, PM-grown seedlings were shorter than required.

The best DQI values, which were calculated as a function of RDW, ADW, TDW, $\mathrm{H}$, and $D$, were also obtained for seedlings grown under the $\mathrm{PM} \times \mathrm{CR}$ treatment (Fig. 1). Theoretically, plants grown on PM substrate with ER fertilization regime may have a high photosynthetic capacity, resistance to damage by insects, and good physiological efficiency (Thompson 1985). However, seedlings grown on SA substrate showed better values when ER is applied (T2 - Fig. 1).

Since there are no studies on critical foliar nutrient concentrations in Pinus leiophylla, we compared our results with those of similar conifer species in the literature. The foliar $\mathrm{N}$ concentration resulting from the exponential addition rate in Pinus leiophylla seedlings ( $2.65 \%$ - Tab. 2 ) exceeds the upper limit of the range indicated for conifers (1.4-2.2\% - Landis 1989), and is higher than the $1.8 \%$ reported for Pinus monticola at the nursery stage (Kasen et al. 2005). Seedlings grown on sawdust had a foliar $P$ concentration of $0.249 \%$, a value similar to those reported by Landis (1989) and Kasen et al. (2005), but higher than the P critical level (0.15\%) reported by Hernández \& Torres (2009) for Pinus montezumae, a species that coexists with $P$. leiophylla in natural ecosystems. Foliar $\mathrm{K}$ concentration in seedlings grown on $\mathrm{PM}$ was $0.451 \%$, which is close to the lower limit of the $0.4-1.5 \%$ range suggested by Landis (1989) and is lower than the critical level for P. montezumae (0.52\% - Hernández \& Torres 2009).

The remarkable differences observed in this study between the nutrient addition rates was attributed, on the one hand, to the dilution of nutrients in those individuals with high biomass grown under the CR fertilization regime, and on the other hand, to the nutrient concentration effect in seedlings grown under the ER treatment (Tab. 2). Theoretically, seedlings subjected to the exponential rate of fertilization are better quality plants in terms of nutrient status. In addition, they are supposed to be better suited for outplanting on low fertility sites, since they can use their nutrient overload to sustain their initial growth (Kasen et al. 2005).

The individuals with the highest $\mathrm{N}$ and $\mathrm{P}$ concentrations resulted from the interaction SA×ER (T2, sawdust substrate + exponential nutrient addition rate); however, this treatment reduced the concentration of $\mathrm{K}$. The reduction in $\mathrm{K}$ concentration and content is caused by its leaching from the sawdust, through a process similar to that occurring throughout soil profiles in sandy sites (Alcántar \& Trejo 2012). Leaching in the sawdust substrate was corroborated by gauging $\mathrm{K}$ with a ionometer in the substrates used in the experiment. Ion extraction from the substrate was done using distilled acidulated water and ammonia acetate (this last chemical was used since the sawdust was fresh). We found a low concentration of $\mathrm{K}^{+}$in the sawdust and a high concentration in the peat-moss substrate, indicating a low availability of this cation for seedlings grown under the SA treatments. As $\mathrm{K}$ is one of the most absorbed cations by seedlings (Moraes \& Benedetti 2000) and its leaching occurs in the substrate, then we expect the availability of $K$ for seedling roots to be severely limited in the treatments with SA. Furthermore, $\mathrm{K}$ losses were likely to take place in both substrates (but especially in SA) as a consequence of the competition between seedlings and microorganisms (Davis et al. 2009). This effect was described by López \& Alvarado (2010) as an antagonistic effect between nutrients, thus decreasing the availability of some of them. Nonetheless, a similar competition can take place under specific conditions, such as high $\mathrm{N}$ concentrations, which favors the presence of microorganisms within the substrate, thereby increasing their nutrient consumption and their competition with plants for these resources. Indeed, the high $\mathrm{N}$ concentrations in our seedlings (Fig. $1 \mathrm{~A}$ ) suggests that $\mathrm{N}$ concentrations was probably high within the substrates.

Nutrient concentration in plant tissue is a function of both its availability in the soil (in this case, substrate), and plant growth rate (López \& Estañol 2007), following the dilution and concentration theory. Hence, individuals grown under the $\mathrm{PM} \times \mathrm{CR}$ treatment, with lower $\mathrm{N}, \mathrm{P}$, and $\mathrm{K}$ concentrations (T3), had higher RGRD and RGRH (Fig. $1 \mathrm{G}$, Fig. $1 \mathrm{H}$ ), and higher dry weights (Fig. $1 \mathrm{~F}$ ), indicating the occurrence of a withintissue dilution effect (López \& Estañol 2007). On the other hand, lower RGRD and RGRH (Fig. 1G, Fig. 1H) occurred in those individuals with higher $\mathrm{N}$ and $\mathrm{P}$ concentrations in $\mathrm{SA} \times \mathrm{ER}\left(\mathrm{T}_{2}\right)$, and lower dry weights (Fig. 1F). At lower growth rates, the nutrients are found within the tissues, in concentrations that can be higher than the critical level, even when nutrient availability in the soil is low (López \& Estañol 2007). Because of the aforementioned dilution and concentration effect, the nutrient status of seedlings is better assessed by considering their nutrient contents, which is more strictly related to nutrient absorption. In our study, the treatment $\mathrm{PM} \times \mathrm{CR}$ (T3) resulted in individuals with the highest $\mathrm{N}, \mathrm{P}$, and $\mathrm{K}$ contents (Fig. 2), followed by the treatment $P M \times E R$. This suggests a larger nutrient availability in the PM substrate, as compared with the SA substrate. As mentioned above, the decreased $\mathrm{N}, \mathrm{P}$, and $K$ availability in the SA substrate could be due to: (i) its low capacity of ion retention; (ii) a high decomposition rate; or (iii) a combination of both processes. In this regard, Wieder (1990) found that the SA substrate had lower cation exchange capacity (CEC) as compared to sphagnum peat (813 vs. $1320 \mu \mathrm{eq} \mathrm{g}^{-1}$ ), being $\mathrm{K}$ the cation showing the lowest absorption in sawdust. Sánchez-Córdova et al. (2008) reported a CEC of 43.6 to $89.4 \mathrm{meq} / 100 \mathrm{~g}$ in a mixture of bark and sawdust. The above evidences suggest that the strong $\mathrm{K}$ deficiency found in SA-grown seedlings in this study could be determined, to a great extent, by the low capacity of sawdust to adsorb K, thus allowing for its leaching.

According to our results, the ER fertilization regime may be used to produce seedlings with greater nutrient reserves and, presumably, with better field performance. In agreement with Kasen et al. (2005), ER treatment proved higher fertilizer use efficiency than CR. On the other hand, the use of PM as a substrate in the nursery may allow to produce seedlings with a better morphological quality. Thus, the combination of PM substrate and ER fertilization should optimize the production of bigger seedlings with high nutrient reserves, while improving the fertilizer use efficiency.

\section{Conclusions}

Hypotheses $\mathrm{Ho}_{1}, \mathrm{Ho}_{2}$, and $\mathrm{Ho}_{3}$ were rejected since the factor "Substrate" (SA and $P M$ ), and "Nutrient addition rate" (ER and CR), as well as their interaction, showed 
significant effects on the morphological and physiological quality variables in P. leiophylla seedlings.

The use of peat-moss as substrate promoted better seedling performances than raw sawdust, in terms of morphological variables and seedling quality. The largest seedlings were obtained with the use of PM substrates.

Both nutrient addition rate and substrate affected foliar N, P, and $\mathrm{K}$ concentrations in P. leiophylla. The use of ER fertilization resulted in higher $\mathrm{N}$ and $\mathrm{P}$ foliar concentrations than using the $C R$ fertilization. PM substrates promoted nutrient dilution within plants, but improved nutrient absorption and final nutrient concentrations when combined with the ER fertilization regime.

Seedlings grown in sawdust were limited by low availability of potassium since this substrate promotes it leaching.

The use of PM as a substrate in combination with ER allows rapid growth rates of seedlings with high nutrient reserves and higher fertilizer use efficiency.

\section{List of abbreviations}

The following abbreviations were used throughout the paper:

- PM: peat-moss;

- SA: Sawdust;

- CR: Constant addition rate;

- ER: Exponential addition rate;

- DQI: Dickson quality index;

- SI: Slenderness index;

- UACh: Universidad Autónoma Chapingo;

- CEC: Cation exchange capacity;

- D: Root-collar diameter;

- H: Total height;

- RGRD: Relative growth rate of diameter;

- RGRH: Relative growth rate of height;

- SDW: Stem biomass;

- RDW: Root biomass;

-100-needle DW: Dry weight of 100 needles;

- SA $\times$ CR: Treatment 1 (T1);

- SA×ER: Treatment 2 (T2);

- PM×CR: Treatment $3(\mathrm{~T} 3)$;

- PM×ER: Treatment 4 (T4).

\section{Acknowledgements}

The authors thank Dr. María de las Nieves Rodríguez Mendoza for her support in the physical and chemical testing of substrates.

\section{References}

Alcántar GG, Trejo TL (2012). Nutrición de cultivos [Crop nutrition]. Colegio de Postgraduados, Montecillo, TX, Mexico, pp. 454. [in Spanish]

Aldana BR, Aguilera RM (2003). Procedimientos y cálculos básicos, útiles en la operación de viveros que producen plantas en contenedor [Basic procedures and calculations for the operation of container-system nurseries]. CONAFOR, Programa Nacional de Reforestación, DF,
Mexico, pp. 45. [in Spanish]

Castelán Munoz N (2014). Estrés hídrico en Pinus leiophylla [Water stress in Pinus leiophylla]. MSc Thesis, Colegio de Postgraduados, Montecillo, TX, Mexico, pp. 8o. [in Spanish] [online] URL: http://colposdigital.colpos.mx:8080/jspui/bitstr eam/10521/2429/1/Castelan_Munoz_N_MC_Fore stal 2014.pdf

CONAFOR (2010). Prácticas de reforestación, manual básico [Afforestation practices, basic

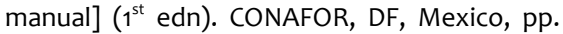
64. [in Spanish]

Davis S, Eggleston K, Pinto R, Dumroese R (2009). Evaluation of three growing media substrates for western larch seedling production at the USDA Forest Service Coeur d'Alene Nursery. In: Proceedings of the meeting "Forest and Conservation Nursery Associations 2008" (Dumroese RK, Riley LE eds). RMRS-P-58, USDA Forest Service, Fort Collins, CO, USA, pp. 37-41. [online] URL: http://www.fs.fed.us/rm/pubs/rm rs_p058/rmrs_p058_037_041.pdf

Dickson A, Leaf AL, Hosnerm JF (1960). Quality appraisal of white spruce and white pine seedling stock in nurseries. The Forestry Chronicle 36 (1): 10-13. - doi: 10.5558/tfc36010-1

Haase DL, Rose R (1995). Vector analysis and its use for interpreting plant nutrient shifts in response to silvicultural treatments. Forest Science 41 (1): 54-66. [online] URL: http://www. ingentaconnect.com/content/saf/fs/1995/0000 0041/00000001/art00006

Hernández ZL, Aldrete A, Ordaz-Chaparro VM, López-Upton J, López-López MA (2014). Crecimiento de Pinus montezumae Lamb. En vivero influenciado por diferentes mezclas de sustratos [Growth of Pinus montezumae Lamb. in the nursery, as influenced by varying substrate mixtures]. Agrociencia 48 (6): 627-637. [in Spanish]

Hernández PF, Torres LS (2009). Niveles críticos nutrimentales preliminares para especies forestales de México a nivel de vivero [Preliminary nutrient critical levels for nursery stage mexican forest species]. Bachelor's thesis, Universidad Autónoma Chapingo. Chapingo, México, pp. 151. [in Spanish]

Johnson JD, Cline ML (1991). Seedling quality of Southern pines. In: "Forest Regeneration Manual” (Duryea ML, Dougherty PM eds). Kluwer Academic Publishers, Netherlands, pp. 159.

Kasen DR, Page-Dumroese DS, Salifu KF, Douglass FJ (2005). Exponential fertilization of Pinus monticola seedlings: nutrient uptake efficiency, leaching fractions, and early outplanting performance. Canadian Journal of Forest Research 35: 2961-2967. - doi: 10.1139/X05-226 Landis T (1989). Manual de viveros para la producción de especies forestales en contenedor [Nursery manual for container production of forest species]. In: "Nutrimentos minerales y fertilización (vol. 4)". USDA, Portland, Oregon, USA, pp. 7-60. [in Spanish]

López LMA, Estañol BE (2007). Detección de deficiencias de hierro en Pinus leiophylla a partir de los efectos de dilución y concentración nutrimental [Detection of iron deficiency in Pinus leiophylla, from dilution and concentra- tion effects]. Terra Latinoamericana 25 (1): 9-15. [in Spanish]

López LMA, Alvarado LJ (2010). Interpretación de nomogramas de análisis de vectores para diagnóstico nutrimental de especies forestales [Interpretation of vector analysis nomograms for nutrient diagnosis of forest species]. Madera y Bosques 16 (1): 99-108. [in Spanish]

Miller BD, Timmer VR (1994). Steady-state nutrition of Pinus resinosa seedlings: response to nutrient loading, irrigation and hardening regimes. Tree Physiology 14: 1327-1338. - doi: 10.1093/treephys/14.12.1327

Moraes G, Benedetti V (2000). Nutrição e fertilização florestal" [Forest nutrition and fertilization]. Instituto de Pesquisas e Estudos Florestais, Piracicaba, SP, Brazil, pp. 427. [in Portuguese]

Musalem M, Martínez G (2003). Monografía de Pinus leiophylla Schl. et Cham. [Monography of Pinus leiophylla Schl. et Cham.]. INIFAP, DF, Mexico, pp. 85. [in Spanish]

Pallardy SG (2008). Physiology of woody plants ( $3^{\text {rd }}$ edn). Academic Press, Boston, MA, USA, pp. 37-41.

Sánchez-Córdova T, Aldrete A, Cetina-Alcalá VM, López-Upton J (2008). Caracterización de medios de crecimiento compuestos por corteza de pino y aserrín [Characterization of pine-barkand-sawdust-made growing media]. Madera y Bosques 14 (2): 41-49. [in Spanish]

Santillán PJ (1991). Silvicultura de las coníferas de la región central [Silvics of the conifers from Central Mexico]. MSc Thesis, Universidad Autónoma Chapingo, División de Ciencias Forestales, Mexico, pp. 305. [in Spanish]

SEMARNAT (2007). Fundación vivero de Coyoacán [Foundation of the Coyoacan Nursery]. SEMARNAT, Mexico, web site. [in Spanish] [online] URL: http://www.viveroscoyoacan.gob .mx/index.php?id=121\&ltemid=123

Thompson BE (1985). Seedling morphological evaluation: what you can tell by looking. In: "Evaluating seedling quality; Principles, Procedures, and Predictive Abilities of Major Test" (Duryea ML ed). Forest Research Lab, Oregon State University, Corvallis, OR, USA, pp. 59-71.

Timmer VR, Stone EL (1978). Comparative foliar analysis of young balsam fir fertilized with nitrogen, phosphorus, potassium and lime. Soil Science Society of American Proceedings 42: 125-130. - doi: 10.2136/sssaj1978.036159950042 $00010027 \mathrm{x}$

UACH/CEC (2011). Evaluación de apoyos de reforestación del PROCOREF 2009-2011 [Evualuation of the PROCOREF 2009-2011 reforestation aids]. Universidad Autónoma Chapingo, Mexico, pp, 293. [in Spanish] [online] URL: http://www.semarnat.gob.mx/archivosanterior es/programas/evaluaciones/2013/Documents/co mplementarias/Evaluacion_Complementaria_P ROCOREF S122.pdf

Wieder RK (1990). Metal cation binding to sphagnum peat and sawdust: relation to wetland treatment of metal-polluted waters. Water, Air and Soil Pollution 53 (3): 391-400. - doi: 10.1007/BF00170751 